\title{
Protein Max
}

National Cancer Institute

\section{Source}

National Cancer Institute. Protein Max. NCI Thesaurus. Code C19951.

Protein max (160 aa, $\sim 18 \mathrm{kDa}$ ) is encoded by the human MAX gene. This protein is involved in transcriptional regulation. 